\title{
Extracellular domain of YWK-II, a human sperm transmembrane protein, interacts with rat Müllerian-inhibiting substance
}

\author{
X. Y. Tian ${ }^{1}$, Y. S. Sha ${ }^{2}$, S. M. Zhang ${ }^{1}$, Y. B. Chen ${ }^{1}$, S. Y. Miao ${ }^{1}$, \\ L. F. Wang ${ }^{1 *}$ and S. S. Koide ${ }^{3}$ \\ ${ }^{1}$ National Laboratory of Medical Molecular Biology, Institute of Basic Medical Sciences, \\ Chinese Academy of Medical Sciences, Peking Union Medical College, 5 Dong Dan San \\ Tiao, Beijing 100005, China; ${ }^{2}$ WHO Collaborating Center for Research in Human \\ Reproduction, 12 Dahui Si, Beijing 100081, China; and ${ }^{3}$ Center for Biomedical Research, \\ Population Council, 1230 York Avenue, New York, NY 10021, USA
}

The YWK-II protein in human spermatozoa is structurally related to the $\beta A 4$-amyloid precursor protein of Alzheimer disease and has high similarity with amyloid precusor homologues. Antibodies to the YWK-II protein agglutinate human spermatozoa and may be a potential cause of infertility. In the present study, a yeast two-hybrid system (MATCHMAKER Two-Hybrid System 2; Clontech, Palo Alto, CA) was used to screen a rat ovary cDNA library for potential ligands capable of interacting with the YWK-II component. Müllerian-inhibiting substance was found to

\section{Introduction}

Sperm membrane proteins probably play an important role in fertilization. A human sperm membrane protein, YWK-II component, has been isolated and characterized, and the coding gene identified (Yan et al., 1990; Huang et al., 2000). The open reading frame consists of 763 codons encoding a polypeptide characteristic of a single transmembrane protein, established by hydropathicity analysis. The transmembrane and cytoplasmic domains of the YWKII component and the $\beta \mathrm{A} 4$-amyloid precursor protein (APP) of Alzheimer disease have $70 \%$ similarity. The similarity is higher with the amyloid precursor homologues, APPH/ APLP2 (Yan et al., 1990; Sprecher et al., 1993). The YWK-II protein and APP can be delineated into three domains: extracellular, hydrophobic transmembrane and cytoplasmic. The extracellular domains of these two proteins are distinctly different. Three peptide segments (YAL-198, YAL201 and YAL-212) corresponding to a section of the extracellular domain of YWK-II were synthesized as a multiple antigen peptide (MAP) and administered to female rats to assess whether anti-YWK-II antibodies may be a cause of infertility. The YAL-198 induced infertility in seven out of 12 female rats and subfertility in two animals. Sera obtained from infertile rats immunized with YAL-198

*Correspondence

Email: wanglf@cdm.imicams.ac.cn interact with the extracellular domain of YWK-II protein. The interaction was confirmed by a binding experiment in vitro and surface plasmon resonance assays. The recombinant Müllerian-inhibiting substance can significantly increase the viability and longevity of human spermatozoa after 5 and $22 \mathrm{~h}$ of incubation, presumably through binding the YWK-II component on the sperm membrane. The results of this study indicate that the YWK-II sperm membrane protein may function as a receptor for Müllerianinhibiting substance. contained higher titres of antibodies compared with those obtained from fertile animals, indicating that anti-YWK-II antibodies possess antifertility activity (Vanage et al., 1992).

A study of the molecular properties of YWK-II component revealed that the cytoplasmic domain binds specifically $\mathrm{G}_{\mathrm{o}}$, a GTP-binding protein (Huang et al., 2000), indicating that the YWK-II component can couple with $\mathrm{G}$ proteins and may activate the signal transduction system of responsive cells. The two-hybrid system relies on the modulating property of eukaryotic site-specific transcriptional activators to generate signals after the interaction of a protein fused to a DNA-binding domain with another protein fused to a transcription-activating domain (Bartel et al., 1993). A yeast two-hybrid system was used to screen a rat ovary cDNA library. The ligands binding to the extracellular domain of YWK-II were identified. In the present paper, the interaction of the extracellular domain of YWK-II with the carboxy-terminus (74 amino acids) of Müllerianinhibiting substance (MIS) was investigated.

\section{Materials and Methods}

\section{Yeast strain}

Saccharomyces cerevisiae strain Y190 was used. The partial genotype of Y190 cells MATa, his3-200, ura3-52, lys2-801, ade2-101, trpl-901, leu2-3, 112, gal44, gal80 $\Delta$, cyhr2, LYS2::GAL1 ${ }_{\text {UAS }}{ }^{-H I S} 3_{\text {TATA }^{-}}{ }^{-H I S 3}$, URA ${ }_{3}: \mathrm{GAI}_{\mathrm{UAS}^{-}}$ GAL1 $1_{\text {TATA }}$-lacZ. 

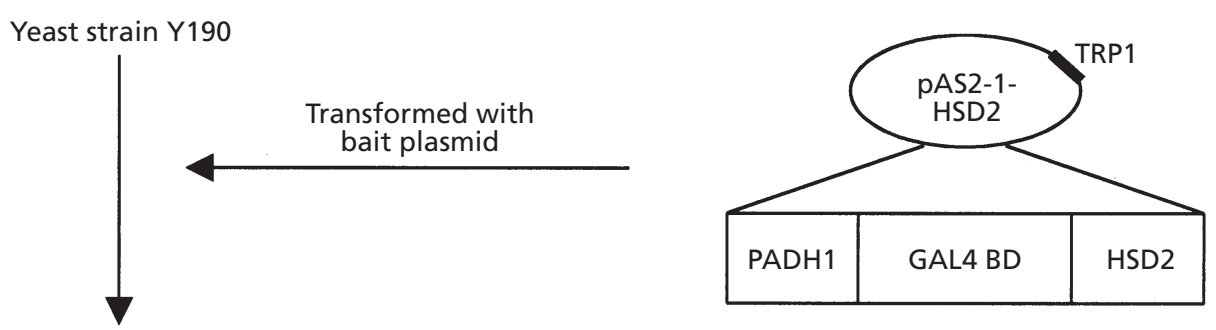

Select transformants on SD/Trp-
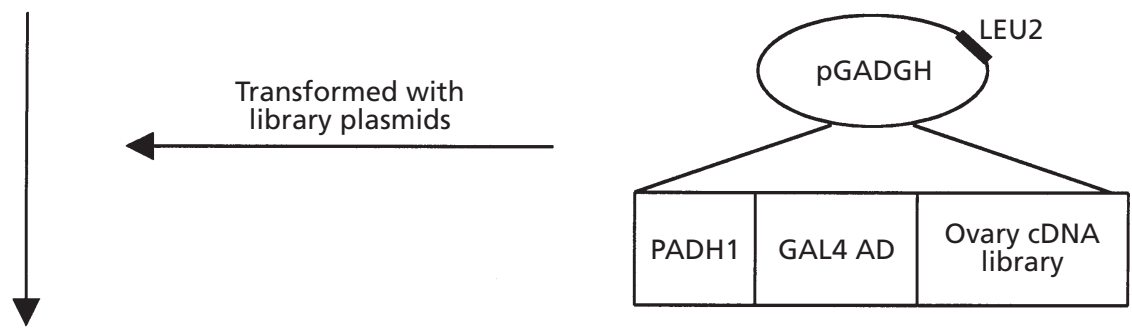

Select transformants on SD/Leu- Trp $^{-} \mathrm{His}^{-}$

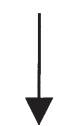

Select LacZ ${ }^{+}$transformants for further analysis

Fig. 1. Experimental strategy to identify proteins that interact with the extracellular domain of the YWK-II component of spermatozoa using the yeast two-hybrid system. Yeast strain Y190 cells were sequentially transformed with pAS2-1-HSD2 as bait plasmid and pGADGH rat ovary cDNAs. Transformants were selected using appropriate media. $\mathrm{His}^{+} \mathrm{LacZ}^{+}$cells were selected and analysed.

\section{Plasmid construction}

A segment (226 amino acids) of HSD2 encoding the extracellular domain contiguous to the transmembrane domain of the deduced YWK-II polypeptide was amplified by PCR and cloned into the GAL4 binding domain of the yeast shuttle vector pAS2-1, yielding pAS2-1-HSD2 to generate a bait plasmid (GAL4 fusion). The cloned DNA inserts were sequenced to ensure that no errors had been introduced during PCR and that the HSD2 sequences were contained within the same reading frame as GAL4 encoding sequence.

\section{Transformation and library screening}

Yeast interaction trap selections were performed (Fig. 1). Yeast transformants were generated by following a modified lithium acetate transformation protocol and grown at $30^{\circ} \mathrm{C}$ using the appropriate synthetic media. Yeast Y190 cells harbouring the pAS2-1-HSD2 were transformed using a rat ovary cDNA library containing the GAL4 transactivation domain in pGADGH (Clontech). Y190 cells possessed both lacZ and HIS3 reporter genes. The transformants were plated on a complete synthetic medium lacking tryptophan, leucine and histidine, but containing $2 \%$ glucose and
25 mmol 3-aminotriazole $\mathrm{I}^{-1}$, an inhibitor of the HIS3 enzyme. The addition of this inhibitor was necessary to suppress background growth of yeast cells that may result from leaky transcription of the HIS3 gene in the absence of any GAL4 function. Large (>2 mm) colonies surviving the selection step were picked and assayed for $\beta$-galactosidase activity using a filter assay by observing the formation of a blue colour in the presence of the chromogenic substrate, X-gal (5-bromo-4-chloro-3-indolyl- $\beta$-D-galactosides). Plasmids were obtained from colonies grown on the nutrient $\left(\mathrm{His}^{-}\right)$ plates and showed positive reaction for $\beta$-galactosidase activity. The isolated plasmids were transformed into Escherichia coli HB101. Yeast Y190 cells were re-transformed with the candidate plasmids either alone or with pAS2-1 or pLAM5 (Clontech) containing the GAL4 DNA binding domain fused to a fragment of laminin to ascertain whether only positive plasmids are transactivated in the presence of pAS2-1-HSD2. Colonies were again assayed for $\beta$-galactosidase activity (Bartel et al., 1993). Positive controls included Y190 cells transformed with pCL1, containing the full-length GAL4, and co-transformed with pVA3-1 and pTD1-1, containing the GA14 BD fused to p53 encoding sequences and GAL4 AD fused to SV40 large Tantigen-encoding sequences. pCL1, pVA3-1 and pTD1-1 


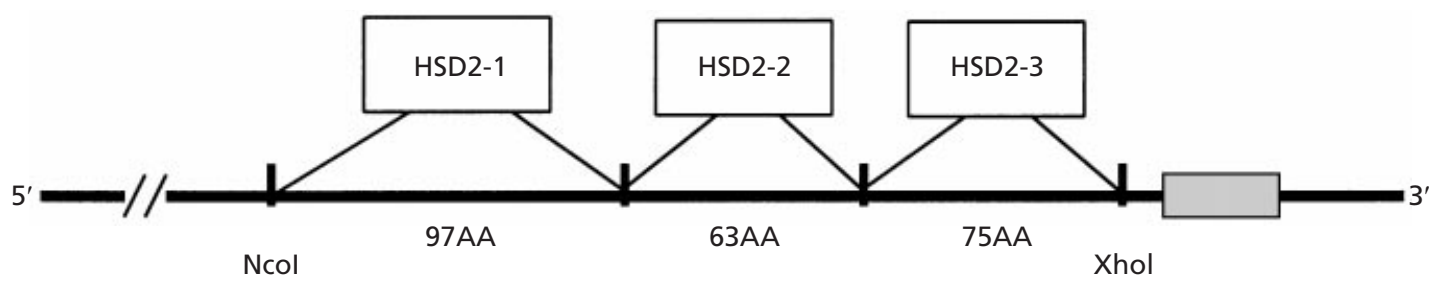

Fig. 2. The three sectors of the YWK-II component of spermatozoa used as bait proteins.

were obtained from Clontech. Plasmids from positive colonies, which were transactivated in the presence of pAS2-1-HSD2, were isolated and sequenced. A search for homology in the amino acid sequences of proteins deposited in the database was performed using the BLAST network service.

\section{Identification of the active segment of 'bait protein'}

HSD2 (Fig. 2) was delineated into three sectors to determine the segment of 'bait protein' that binds to the partner protein: (1) an alternatively spliced segment in the mid-portion composed of 63 amino acids; (2) a segment of 75 amino acids corresponding to the C-terminus, containing the 16 amino acid peptide, a potential antifertility immunogen; and (3) the remaining 97 amino acid segment of the $\mathrm{N}$-terminus. All three sectors were fused individually to GAL4 BD in pAS2-1, generating three smaller bait proteins. Subsequently, the positive plasmid was co-transformed with each of these smaller bait proteins transformed into yeast cells. The culture media were assayed for $\beta$-galactosidase activity to verify and quantify the two-hybrid interactions.

\section{Construction of protein expression clones}

The Ncol/Sall fragment of the pAS2-1-HSD2 encoding the 226 amino acid polypeptide (HSD226) of HSD2 was ligated into pET-30a(+) (Novagen, Madison, WI). The 222 bp positive cDNA insert in the AD/library plasmid pGADGH (clone 17\#) encodes a polypeptide identical to the segment, corresponding to amino acid residues 303-376 of rat MIS (Fig. 3) (Haqq et al., 1992). This segment was excised and cloned into the pET-30a(+). The same polynucleotide segment encoding rMIS(303-376) was also ligated into pGEX-4T-3 (Amersham Pharmacia Biotech, Uppsala). The nucleotide sequences of the cloned inserts were validated by analysis.

\section{Expression and purification of recombinant proteins}

All recombinant protein expression plasmids were transformed into the E. coli strain BL21. The DNA insert in the pET-30a(+) was expressed as $\mathrm{His}_{6}$-tagged fusion proteins and the insert in the pGEX-4T-3 was expressed as glutathione S-transferase (GST) fusion protein. The $\mathrm{His}_{6}$ tagged HSD226 and $\mathrm{His}_{6}$-tagged $\mathrm{rMIS}(303-376)$ were purified using Ni-NTA resin (Novagen) according to the manufacturer's protocol. GST-rMIS(303-376) was purified on a glutathione Sepharose 4B (Amersham Pharmacia Biotech) column as reported by Frangioni and Neel (1993). The purified fusion proteins were dialysed overnight against PBS $\left(138 \mathrm{mmol} \mathrm{NaCl} \mathrm{I}-1,2.7 \mathrm{mmol} \mathrm{KCl} \mathrm{l}{ }^{-1}, 10 \mathrm{mmol}\right.$ $\mathrm{Na}_{2} \mathrm{HPO}_{4} \mathrm{l}^{-1}, 1.8 \mathrm{mmol} \mathrm{KH} \mathrm{PO}_{4} \mathrm{l}^{-1}, \mathrm{pH}$ 7.4). Total protein concentrations were determined by the Lowry (1951) method.

\section{Binding experiment in vitro}

Purified $\mathrm{His}_{6}$-tagged HSD226 (2.8 nmol) in $100 \mu \mathrm{l} \mathrm{PBS}$ was loaded onto a glutathione Sepharose 4B column (column volume $50 \mu \mathrm{l}$ ) prebound with GST $(3 \mathrm{nmol}$ ) or GST-rMIS(303-376) $(2.5 \mathrm{nmol})$. Each column was then washed with 50 column volumes of PBS. The columns were eluted with $100 \mu$ l elution buffer, 50 mmol Tris- $\mathrm{HCl} \mathrm{I}^{-1}, \mathrm{pH}$ 8.0, $10 \mathrm{mmol}$ reduced glutathione $\mathrm{I}^{-1}$. The eluted proteins were analysed by SDS-PAGE and the separated proteins stained with Coomassie brilliant blue.

\section{Surface plasmon resonance assays}

All surface plasmon resonance (SPR) assays were performed using IAsys (Affinity Sensors, Cambridge, UK). Purified GST-rMIS(303-376) was immobilized in a carboxymethyl dextran-coated cuvette (Affinity Sensors), activated by treatment with $\mathrm{N}$-hydroxysuccinimide and 1 ethyl-3-(3-dimethylaminopropyl) carbodiimide according to the manufacturer's instructions. With each cycle of the experiment, $50 \mu \mathrm{l} \mathrm{His}_{6}$-tagged HSD226 in PBS-T $(138 \mathrm{mmol}$ $\mathrm{NaCl} \mathrm{I-1}, 2.7 \mathrm{mmol} \mathrm{KCl} \mathrm{I-1}, 10 \mathrm{mmol} \mathrm{Na} \mathrm{HPO}_{4} \mathrm{I}^{-1}, 1.8$ mmol $\mathrm{KH}_{2} \mathrm{PO}_{4} \mathrm{I}^{-1}, 0.05 \%(\mathrm{v} / \mathrm{v})$ Tween 20) was added over the chip. The chip was regenerated after each cycle by washing with $50 \mu \mathrm{l}$ of 1 mol formic acid $\mathrm{I}^{-1}$ three times and

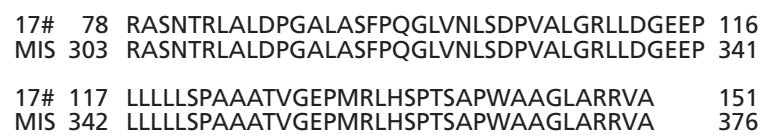

Fig. 3. Alignment of related segments of the deduced polypeptides of positive plasmid $17 \#$ and rat Müllerian-inhibiting substance (MIS). Within a stretch of 74 amino acids, 17 \# plasmid polypeptide and rMIS share $100 \%$ sequence identity. 


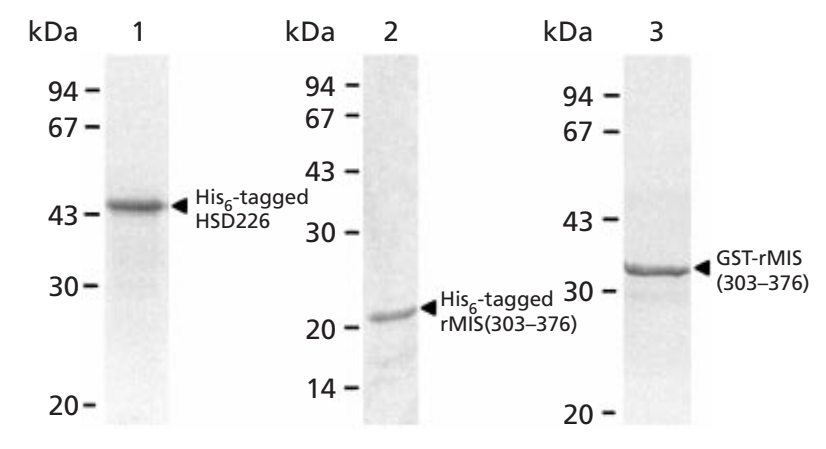

Fig. 4. Purified recombinant fusion proteins analysed by SDSPAGE. Ten or twelve per cent polyacrylamide gels were used and proteins were stained with Coomassie brilliant blue. The fusion proteins were analysed: $\mathrm{His}_{6}$-tagged HSD226 (lane 1, 10\% gel), $\mathrm{His}_{6}$-tagged rat Müllerian-inhibiting substance (MIS)(303-376) (lane 2, 12\% gel), GST-rMIS(303-376) (lane 3, 10\% gel).

PBS-T three times. The response of the GST-rMIS(303-376)coated chip with $50 \mu \mathrm{l}$ PBS-T was fixed as the baseline. Data were analysed using IAsys FASTfit software. Six concentrations $(11.4,8.57,5.71,2.86,1.14$ and $0.57 \mu \mathrm{mol}$ $\mathrm{I}^{-1}$ ) of $\mathrm{His}_{6}$-tagged HSD226 were used to calculate the $K_{\mathrm{D}}$ value of $\mathrm{His}_{6}$-tagged HSD226 binding to GST-rMIS(303-376).

Determination of the effect of His ${ }_{6}$-tagged rMIS(303-376) on the viability and longevity of human spermatozoa

Human ejaculates were obtained from seven healthy adults between the ages of 24 and 36 years. Semen samples were collected into sterile containers by masturbation after a period of sexual abstinence of 3-5 days and allowed to liquefy for $40 \mathrm{~min}$ in an incubator at $37^{\circ} \mathrm{C}$. Semen baseline parameters were determined based on the World Health Organization protocol and criteria (WHO, 1994). BWW medium (2 ml) containing $3.5 \mathrm{mg} \mathrm{BSA} \mathrm{ml}^{-1}$ (Boehringer, Mannheim) was added to each round bottomed sterile tube. The swim-up procedure was performed: a $0.5 \mathrm{ml}$ sample of liquefied semen was added to the tube, and the tube was sealed with Parafilm and placed in an incubator at $37^{\circ} \mathrm{C}$ for $1 \mathrm{~h}$. The supernatants were aspirated gently and the sperm specimens were pooled. The spermatozoa were washed twice with BWW and collected by centrifugation at $300 \mathrm{~g}$ for $5 \mathrm{~min}$ at room temperature. The sperm concentration was adjusted to $20 \times 10^{6}$ spermatozoa $\mathrm{ml}^{-1}$. A sperm viability assay was performed according to the method of Siow et al. (1998) which involved an eosin-nigrosin exclusion test (WHO, 1994). The sperm suspension was divided into two fractions and $0.5 \mu \mathrm{g} \mathrm{His}_{6}$-tagged rMIS(303-376) in PBS was added to one fraction and an equal volume of PBS was added to the other fraction to serve as a control. Both fractions were incubated at $37^{\circ} \mathrm{C}$. Sperm viability and longevity were evaluated at 0,5 and $22 \mathrm{~h}$ of incubation. At each time-point, 100 spermatozoa were counted and scored as being live (exclusion of eosin) or dead (sperm permeated with eosin). The percentages of viable spermatozoa between the experimental and control groups were compared and the significance of the differences determined statistically using Student's $t$ test.

\section{Results}

Interaction of YWK-II with Müllerian-inhibiting substance in a yeast two-hybrid system

A yeast two-hybrid system transformed with rat ovary cDNA library was screened for components that bind to the extracellular domain of YWK-II. An ovarian protein was found attached to the YWK-II probe. The extracellular domain of YWK-II fused to the GAL4 binding region was bound to a target protein fused to the GAL4-activating domain. The binding was established by measuring the transcriptional activities of the two reporter genes, HIS3 and lacZ. Both genes contained upstream the GAL4 binding sites. Among the approximately $2.1 \times 10^{6}$ transformants, 860 colonies were found growing on the plates lacking tryptophan, leucine and histidine, although the size of the colonies varied over a wide range. Occurrence of the transformation was verified by measuring the $\beta$ galactosidase activity of the cells. Among the $\mathrm{His}^{+}$colonies, 127 isolates gave positive reactions. Plasmids were isolated from 102 yeast colonies and transformed into E. coli HB101 that were selected nutritionally for the LEU2 gene. The process was repeated, and the cloned plasmids were subjected to PCR amplification. The insert was identified by restriction endonuclease digestion map analysis. On the basis of the results, 31 colonies were selected and their plasmids isolated and reintroduced into the Y190 cells, either alone or together with pAS2-1-HSD2, or in combination with control plasmids, encoding other DNAbinding domain hybrids. After these rigorous selection steps, 24 plasmids were established as authentic specimens.

The nucleotide sequences of the plasmid segments were determined and their encoded polypeptides deduced. The amino acid sequences of the deduced polypeptides were compared with those proteins deposited in the database using the BLASTP program. One of the clones, 17\# contained an insert identical to the carboxy-terminus (74 amino acids) of the open reading frame of rat MIS (Fig. 3). Moreover, only the mid-portion of the bait protein, consisting of alternatively spliced region of 63 amino acids, designated HSD2-2, interacted with MIS (Fig. 2). Quantitative measurement of $\beta$-galactosidase activity was performed to determine the affinity of the bait protein-MIS interaction. The affinity of MIS with the mid-portion segment (HSD2-2) of the bait protein and with the entire YWK-II was 30.4 and 8.22 expressed as $\beta$-galactosidase units, respectively, showing that the mid-segment was the reactive site.

\section{Recombinant protein expression and purification}

The 226 amino acid fragment of HSD2 used as bait in the yeast two-hybrid system was cloned into pET-30a(+) and 


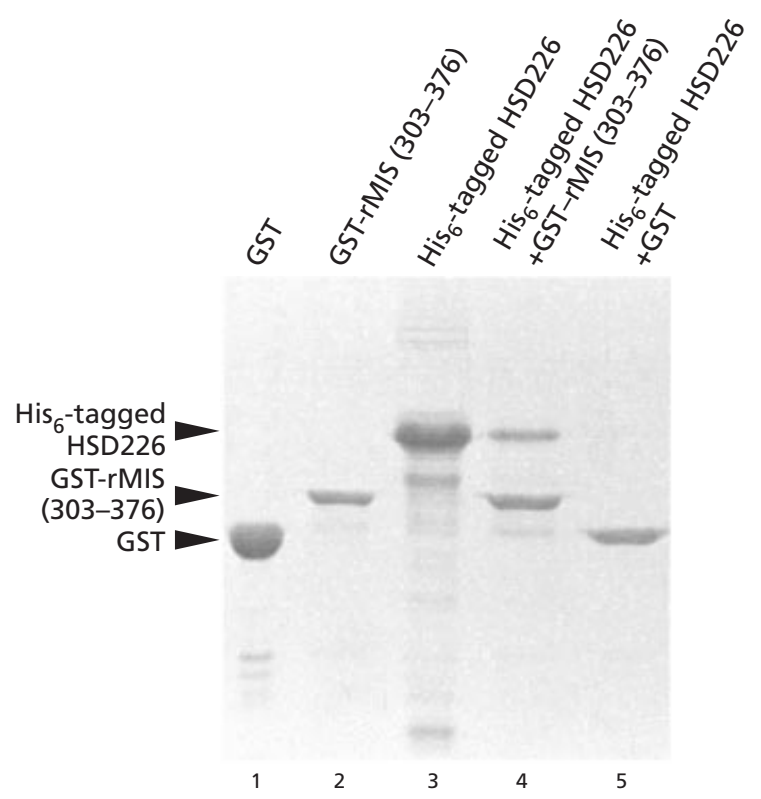

Fig. 5. SDS-PAGE analysis of $\mathrm{His}_{6}$-tagged HSD226 bound to glutathione S-transferase (GST)-rat Müllerian-inhibiting substance (MIS)(303-376). Purified $\mathrm{His}_{6}$-tagged HSD226 was loaded onto a glutathione Sepharose 4B column prebound with GST or GST-rMIS(303-376). The bound proteins were eluted with buffer containing reduced glutathione, collected and analysed by SDSPAGE. Lanes 1-3: control buffer; lanes 1 and 5: GST; lanes 2 and 4: GST-rMIS(303-376); lanes 3-5: His 6 -tagged HSD226.

expressed as a $\mathrm{His}_{6}$-tagged fusion protein. The $\mathrm{His}_{6}$-tagged HSD226, expressed in a soluble form, was purified using $\mathrm{Ni}$-nitrilo-tri-acetic acid (NTA) resin under native conditions. The fusion protein migrates as a single band on SDSPAGE (lane 1, Fig. 4). The 222 bp positive cDNA insert in the AD/library plasmid pGADGH (clone 17\#) encoding the rMIS(303-376) was cloned into pET-30a(+) and pGEX-4T-3. The major part of $\mathrm{His}_{6}$-tagged $\mathrm{rMIS}(303-376)$ was expressed as inclusion bodies and a lesser amount in the soluble form, which was purified under native conditions. However, GST-rMIS(303-376) was expressed mainly as inclusion bodies and purified by the method of Frangioni and Noel (1993).

\section{Direct interaction of the extracellular domain of $Y W K-I I$ with rMIS(303-376)}

The interaction of the extracellular domain of YWK-II with $\mathrm{rMIS}(303-376)$ in the yeast two-hybrid system was confirmed by the binding experiment in vitro. Purified $\mathrm{His}_{6}{ }^{-}$ tagged HSD226 was loaded onto a glutathione Sepharose 4B column prebound with GST or GST-rMIS(303-376). The bound proteins were eluted with reduced glutathione and subsequently analysed by SDS-PAGE and protein staining. $\mathrm{His}_{6}$-tagged HSD226 was bound to GST-rMIS(303-376) (lane 4, Fig. 5) but not to GST (lane 5, Fig. 5).
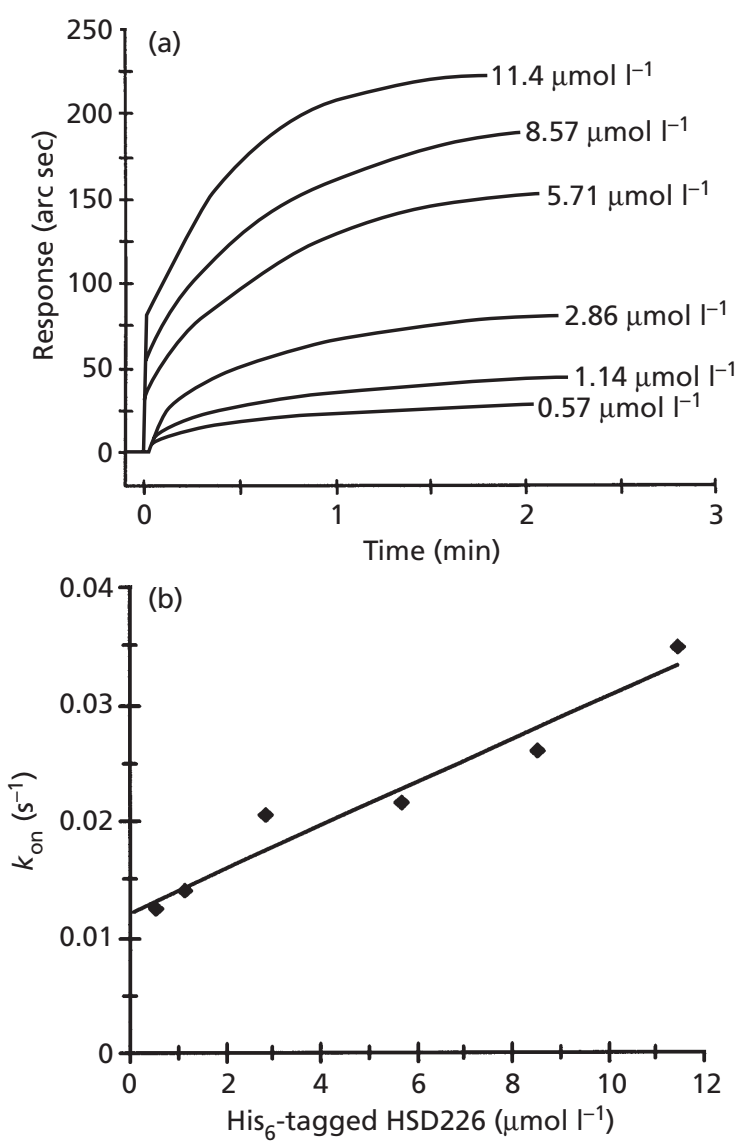

Fig. 6. Surface plasmon resonance assay of the binding of $\mathrm{His}_{6}{ }^{-}$ tagged HSD226 to glutathione S-transferase (GST)-rat Müllerianinhibiting substance (MIS)(303-376). (a) Response curves with various concentrations of $\mathrm{His}_{6}$-tagged HSD226; (b) plot of pseudofirst order rate constant $\left(k_{\text {on }}\right)$ values versus $\mathrm{His}_{6}$-tagged HSD226 concentration. From the linear plot of $k_{\text {on }}$ values at various protein concentrations, the association and dissociation rate constants, $k_{\text {ass }}$ and $k_{\text {diss, }}$ are the slope and $y$ intercept, respectively. The equilibrium constant, $K_{\mathrm{D}}=6.57 \mu \mathrm{mol} \mathrm{I}^{-1}$ was derived as the ratio of $k_{\text {diss }}: k_{\text {ass }}$.

\section{Kinetics of interaction between $\mathrm{His}_{6}$-tagged HSD226 and $\mathrm{rMIS}(303-376)$}

The kinetics of the interaction of $\mathrm{His}_{6}$-tagged HSD226 with rMIS(303-376) were measured by SPR analysis (Fig. 6). Six different concentrations of $\mathrm{His}_{6}$-tagged HSD226 were used. The association rate, $k_{\text {ass }}$ and the dissociation rate, $k_{\text {diss, }}$, were obtained as the intercept and from the gradient of the plot of $k_{\text {on }}$ versus ligand concentrations (Fig. 6), using the software FASTfit. The uncorrected values were as follows: $k_{\text {diss }}($ intercept $)=0.0121873 \mathrm{~s}^{-1} ; k_{\text {ass }}($ gradient $)=$ $1854.54 \mathrm{~s}^{-1} \mathrm{~mol}^{-1} ; K_{\mathrm{D}}\left(k_{\text {diss }} / k_{\text {ass }}\right)=6.57 \mu \mathrm{mol} \mathrm{I}^{-1}$.

Effect of the His H-tagged MIS(303-376) on viability and longevity of human spermatozoa

Mean sperm volume of the fresh ejaculates from the 


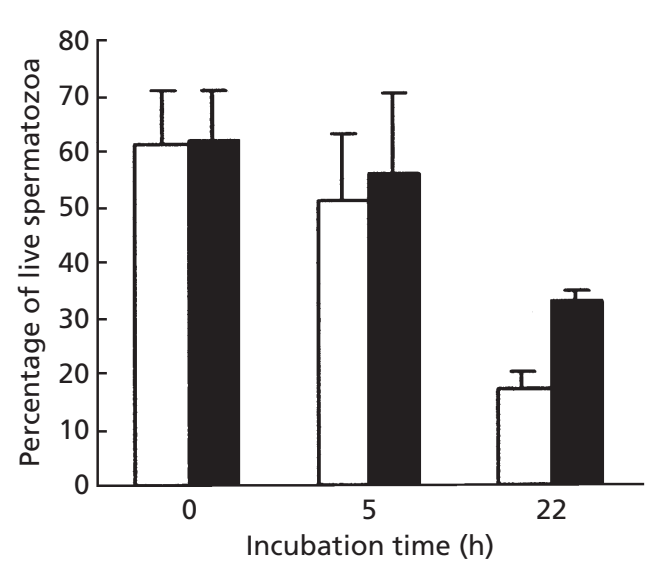

Fig. 7. Effect of $\mathrm{His}_{6}$-tagged rat Müllerian-inhibiting substance (MIS)(303-376) on the viability and longevity of spermatozoa. The viability value is the percentage (mean $\pm \mathrm{SD}$ ) of initial motile spermatozoa counted at $0 \mathrm{~h}$. Spermatozoa were incubated with

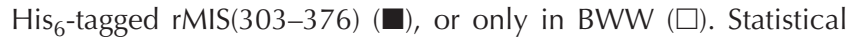
analysis was performed by Student's $t$ test, $P<0.01$ at $5 \mathrm{~h}$, $P<0.001$ at $22 \mathrm{~h}$.

seven donors was $4.5 \pm 0.42 \mathrm{ml}$ (range $3-6 \mathrm{ml}$ ). The mean fresh sperm concentration was $195.9 \pm 13.9 \times 10^{6}$ spermatozoa $\mathrm{ml}^{-1}$ (range 145-246 spermatozoa $\mathrm{ml}^{-1}$ ) and the mean percentage of motile spermatozoa was $72.3 \pm 2.9 \%$ (range $63.0-83.9 \%$ ). The effect of MIS on the viability and longevity of human spermatozoa in vitro was determined (Fig. 7). Significant increases in the viability and longevity of spermatozoa were evident at 5 and $22 \mathrm{~h}$ of incubation, as determined by Student's $t$ test (two-tailed comparison of means for paired samples).

\section{Discussion}

Yeast two-hybrid systems have been used to identify many novel interactions of proteins as they provide a simple but reliable transcriptional assay for detecting specific proteinprotein interactions in yeast. Although many novel associations are predicated by the two-hybrid library screens and may reflect biological associations of two proteins in vivo, the functional co-relevance of two proteins scored as interacting in the two-hybrid system is unclear. The basis for the occurrence of false positives needs to be clarified. Some strategies have been developed to identify the causes (Serebriiskii, 2000). In the present study, 24 positive clones were identified and sequenced, and a search for homologous sequences was performed using the BLAST network service. Among these sequences, nine are new expressed sequence tags (ESTs) and known ESTs that are difficult to evaluate since the kind of proteins, if any, they encode is unknown. The other sequences are common extraneous contaminants that occur with the two-hybrid systems: three mitochondrial proteins, one zinc finger protein, two heat shock proteins, three ribosomal proteins and one cytoskeletal protein (for additional information, see the
Golemis Lab Web Site, www.fccc.edu:80/research/labs/ golemis). In addition, two segments of $S$. cerevisiae chromosome II were identified that were probably introduced when the library was constructed. The two cytoplasmic proteins, rat neurabin (Burnett et al., 1998) and rat Bat3 (Ozaki et al., 1999), are apparently false positive since the extracellular domain of YWK-Il protein is used as bait protein. Rat MIS is considered to be a genuine reactant because it is a hormone capable of interacting with the YWK-II protein, a putative receptor. MIS is a $140 \mathrm{kDa}$ homodimeric glycoprotein secreted by fetal Sertoli cells during the development of mammalian testis (Blanchard and Josso, 1974; Donahoe et al., 1977). The hormone promotes regression of the embryonic Müllerian ducts (Donahoe et al., 1982), known to be the primordial structures of the female reproductive system. This activity of MIS assures the phenotypic development of the male reproductive tract. The gene coding rat MIS is composed of five exons encoding the precursor protein composed of 553 amino acids, which contains a leader sequence of 24 amino acids (Haqq et al., 1992). A failure to express MIS activity by the embryos at the critical time during the differentiation of the gonadal anlage to testis will result in the postnatal retention of the Müllerian structures. Although MIS was believed initially to be produced only by the testes and is essential during fetal and early neonatal life, subsequent studies show that this hormone is also produced by ovarian granulosa cells (Vigier et al., 1984; Takahashi et al., 1986), indicating that MIS is not a male-specific substance. A continuous production of MIS by the ovary and testis seems to occur postnatally, to the extent that it attains detectable concentrations in the blood of adult men and women (Hudson et al., 1990; Lee et al., 1996). In men, the highest MIS concentration (50-70 $\mathrm{ng} \mathrm{ml} \mathrm{m}^{-1}$ ) occurs during the perinatal period and is maintained until adulthood (Hudson et al., 1990). Pre-adolescent females begin to produce measurable amounts of circulating MIS equivalent to that of adult males; however, this decreases to undetectable amounts at the onset of menopause (Hudson et al., 1990; Lee et al., 1996). The findings that MIS is secreted by the ovary in women and is being produced throughout adulthood in men indicate that this hormone plays a functional role in the development of multiple organ systems in addition to its action as promoter of Müllerian duct regression.

MIS in human seminal plasma may influence sperm vitality (Fallat et al., 1996). In healthy men categorized on the basis of WHO parameters as producing normal semen, the MIS concentration in seminal plasma ranges from 0.5 to $3.6 \mathrm{ng} \mathrm{ml}^{-1}$. Seminal plasma ranges are significantly higher in teratozoospermic men (0.5-17.8 $\mathrm{ng} \mathrm{m}^{-1}$ ) (Fallat et al., 1996). MIS tends to increase the longevity of motility and viability of fresh and cryopreserved spermatozoa (Siow et al., 1998). Similar results were obtained in the present study using a segment of MIS. These effects of MIS may be mediated by its binding to specific receptors on the sperm membrane. Examination by transmission electron 
microscopy shows that MIS binds mainly to the surface of the sperm head, whereas practically no binding sites are found on the tail. In addition, spermatozoa from normal fertile men possess a larger number of MIS binding sites than those from subfertile men (Fallat et al., 1998). Since YWK-II is a transmembrane protein located at the equatorial sector of the human sperm head and exhibits the properties of a receptor (Yan et al., 1990; Sprecher et al., 1993), the extracellular domain of YWK-II protein may act as the specific receptor for MIS. The present study shows that a segment of rMIS(303-376) binds to the 226 amino acids sector of the extracellular domain of YWK-II, determined in yeast cells using an in vitro system. The heterogeneous system used in the present study is acceptable but not ideal, since the binding segments of both YWK-II protein and MIS are highly homologous between the human and rat forms, that is, 91 and $79 \%$, respectively (data obtained using the BLAST network service). Taking all these results together, it is reasonable to hypothesize that the YWK-II protein is the receptor of MIS. Although the affinity between $\mathrm{His}_{6}$-tagged HSD226 and GST-rMIS(303-376) is low compared with the interaction of other ligands and their respective receptors, the bonding between MIS and YWK-II in their native conformation in vivo may be stronger. Furthermore, their affinity may be high should MIS acts as a dimer, thereby triggering dimerization of the receptor.

MIS is also known to be involved in ontogenic regulation, mediated through its binding to cell membrane receptors (Lee and Donahoe, 1993; Teixeira et al., 1996). MIS blocks protein phosphorylation in A-431 cells by inhibiting phosphorylation of epidermal growth factor (EGF) receptor mediated by tyrosine kinase (Coughlin et al., 1987). In addition, MIS is involved in the ontogenic regulation of fetal lung development by modulating EGF receptor phosphorylation (Catlin et al., 1990, 1991). However, both the induction of capacitation and the occurrence of the obligatory acrosomal reaction during sperm-egg interaction involves protein phosphorylation mediated by tyrosine kinase (Furuya et al, 1993; Yanagimachi, 1994; Burks et al., 1995). Should the relationship between MIS binding and inhibition of protein phosphorylation in A-431 cells and fetal lung cells be a general cellular event, the interaction of MIS with YWK-II protein on the sperm surface may promote longevity and viability of motile spermatozoa, prevent capacitation or block the acrosomal reaction during fertilization. The cytoplasmic domain of YWK-II protein is coupled to the GTP-binding protein $G_{0}$ (Huang et al., 2000). Thus the binding of YWK-II protein with MIS would stimulate the $\mathrm{G}_{\mathrm{O}^{-}}$ mediated signal transduction pathway via its intracellular domain and influence sperm metabolism. The link between this pathway and protein phosphorylation by tyrosine kinase needs to be established.

In summary, the finding that YWK-II sperm membrane protein interacts with MIS indicates that it may function as the receptor for the hormone. Further studies need to be performed to elucidate the mechanism by which the two molecules working co-operatively can sustain the viability and the fertilizing potential of spermatozoa.

Supported by the Rockefeller Foundation, National Natural Sciences Foundation of China, and Ministry of Science and Technology, PR China.

\section{References}

Bartel P, Chien CT, Sternglanz R and Fields S (1993) Elimination of false positives that arise in using the two-hybrid system Biotechniques 14 920-924

Blanchard MG and Josso N (1974) Sources of the anti-Müllerian hormone synthesized by the fetal testis: Müllerian inhibiting activity of fetal bovine Sertoli cells in tissue culture Pediatrics Research 8 968-971

Burks DJ, Carballada R, Moore HD and Saling PM (1995) Interaction of a tyrosine kinase from human sperm with the zona pellucida at fertilization Science 269 83-86

Burnett PE, Blackshaw S, Lai MM, Qureshi IA, Burnett AF, Sabatini DM and Snyder SH (1998) Neurabin is a synaptic protein linking p70 S6 kinase and the neuronal cytoskeleton Proceedings National Academy of Sciences USA 95 8351-8356

Catlin EA, Powell SM, Manganaro TF, Hudson PL, Ragin RC, Epstein J and Donahoe PK (1990) Sex-specific fetal lung development and Müllerian inhibiting substance American Review of Respiratory Diseases 141 466-470

Catlin EA, Uitvlugt ND, Donahoe PK, Powell DM, Hayashi M and MacLaughlin DT (1991) Müllerian inhibition substance block epidermal growth factor receptor phosphorylation in fetal lung membranes Metabolism 40 1178-1184

Coughlin JP, Donahoe P, Budzik GP and MacLaughlin DT (1987) Müllerian inhibiting substance blocks autophosphoryation of the EGF receptor by inhibiting tyrosine kinase Molecular and Cellular Endocrinology 49 75-86

Donahoe PK, Ito Y, Price M and Hendren WH (1977) Müllerian inhibiting substance activity in bovine fetal, newborn and prepubertal testes Biology of Reproduction 16 238-243

Donahoe PK, Budzik GP, Trelstad R, Mudgett-Hunter M, Fuller A Jr, Hutson JM, Ikawa H, Hayashi A and MacLaughlin D (1982) Müllerian inhibiting substance: an up-date Recent Progress in Hormone Research 38 279-330

Fallat ME, Siow Y, Belker AM, Boyd JK, Yoffe S and MacLaughlin DT (1996) The presence of Müllerian inhibiting substance in human seminal plasma Human Reproduction 11 2165-2169

Fallat ME, Siow Y, Klar EA, Belker AM and MacLaughlin DT (1998) The presence of Müllerian inhibiting substance binding sites in human sperm Journal of Urology 159 2210-2214

Frangioni JV and Neel BG (1993) Solubilization and purification of enzymatically active glutathione S-transferase (pGEX) fusion proteins Analytical Biochemistry 210 179-187

Furuya S, Endo Y, Oba M, Suzuki S and Nozawa S (1993) Effect of epidermal growth factor on human sperm capacitation Fertility and Sterility 60 905-910

Haqq C, Lee MM, Tizard R, Wysk M, DeMarinis J, Donahoe PK and Cate RL (1992) Isolation of the rat gene for Müllerian inhibiting substance Genomics 12 665-669

Huang P, Miao SY, Fan HY, Sheng Q, Yan YC, Wang LF and Koide SS (2000) Expression and characterization of the human YWK-II gene, encoding a human sperm membrane protein related to Alzheimer's amyloid precursor protein Molecular Human Reproduction 6 1069-1078

Hudson PL, Dougas I, Donahoe PK, Cate RL, Epstein J, Pepinsky RB and MacLaughlin DT (1990) An immunoassay to detect human Müllerian inhibiting substance in males and females during normal development Journal of Clinical Endocrinology and Metabolism 70 16-22

Lee MM and Donahoe PK (1993) Müllerian inhibiting substance: a gonadal hormone with multiple functions Endocrine Review 14 152-164

Lee MM, Donahoe PK, Hasegawa T, Silverman B, Crist GB, Best S, 
Hasegawa Y, Noto RA, Schoenfeld D and MacLaughlin DT (1996) Müllerian inhibiting substance in humans: normal levels from infancy to adulthood Journal of Clinical Endocrinology and Metabolism 81 571-576

Lowry OH, Rosebrough NJ, Farr AL and Randall RJ (1951) Protein measurement with the folin phenol reagent Journal of Biological Chemistry 193 265-275

Ozaki T, Hanaoka E, Naka M, Nakagawara A and Sakiyama S (1999) Cloning and characterization of rat BAT3 cDNA DNA and Cell Biology 18 503-512

Serebriiskii I, Estojak J, Berman M and Golemis EA (2000) Approaches to detecting false positives in yeast two-hybrid systems Biotechniques 28 328-330, 332-336

Siow Y, Fallat ME, Amin FA and Belker AM (1998) Müllerian inhibiting substance improves longevity of motility and viability of fresh and cryopreserved sperm Journal of Andrology 19 568-572

Sprecher CA, Grant FJ, Grimm G, O'Hara PJ, Norris F, Norris K and Foster DC (1993) Molecular cloning of the cDNA for a human amyloid precursor protein homology: evidence for a multigene family Biochemistry 32 4481-4486

Takahashi M, Hayashi M, Manganaro TF and Donahoe PK (1986) The ontogeny of Müllerian inhibiting substance in granulosa cells of the bovine ovarian follicle Biology of Reproduction 35 447-453

Teixeira J, He WW, Shah PC, Morikawa N, Lee MM, Catlin EA, Hudson PL, Wing J, Maclaughlin DT and Donahoe PK (1996) Developmental expression of a candidate Müllerian inhibiting substance type II receptor Endocrinology 137 160-165

Vanage G, Lu YA, Tam JP and Koide SS (1992) Infertility induced in rats by immunization with synthetic peptide segments of a sperm protein Biochemical and Biophysical Research Communication 183 538-543

Vigier B, Picard JY, Tran D, Legeai L and Josso N (1984) Production of antiMüllerian hormone: another homology between Sertoli and granulosa cells Endocrinology 114 1315-1320

WHO (1994) Laboratory Manual for the Examination of Human Semen and Sperm-Cervical Mucus Interaction 3rd Edn. Special Programme of Research, Development and Research Training in Human Reproduction, WHO, Geneva

Yan YC, Bai Y, Wang LF, Miao SY and Koide SS (1990) Characterization of cDNA encoding a human sperm membrane protein related to A4 amyloid protein Proceedings National Academy of Sciences USA $\mathbf{8 7}$ 2405-2408

Yanagimachi R (1994) Mammalian fertilization. In The Physiology of Reproduction pp 189-317 Eds E Knobil and JD Neill. Raven Press, New York

Received 4 September 2000.

First decision 20 November 2000.

Revised manuscript received 29 January 2001.

Accepted 8 February 2001. 